extraordinarily inefficient converters of crop products into protein. Whereas the cow puts on only 1 pound of protein a day, pound for pound growing soya beans put on 100 pounds a day, yeasts put on 100,000 pounds a day and bacteria put on $10^{14}$ pounds a day.

Dr F. Moran (British Petroleum, Surrey) elucidated the possibility of producing protein foodstuffs from petroleum byproducts. One of the plants run by British Petroleum is turning out 17,000 tons of this food a year, and future plants will have an annual capacity of 100,000 tons. The protein in question has been found to be nutritious and safe and Dr Moran said that it has been cleared as animal foodstuffs in France, Italy, Great Britain, Germany, Denmark and Holland. Clinical tests for human foods were being done and their possible use as additives in baby foods or confectionery was being considered.

On the subject of pollution Dr C. F. Seyfried (Technical University, Hanover) made the prediction that the technique of reverse osmosis would play a very important part in the future treatment of effluents and Dr I. Tookos (Research Institute for Water Resources Development, Budapest), in her presentation on the treatment of organic effluents from the food industry, was quick to point out that biological degradation was preferable.

Dr H. J. Hueck (Central Laboratory TNO, Delft) predicted that the future use of mercury will be severely restricted, and he discussed in particular the use of protective materials containing copper and mercury. "The River Rhine," he said, "carried some 2,900 tons of copper and 70 tons of mercury each year, while Dutch industry-such as metal plating and paint productionspews forth annually 500 tons of copper and 46 tons of mercury."

\section{PROTEINS \\ Micromethods}

from our Molecular Biology Correspondent

THOSE horny-handed toilers of biochemistry who have spent the greater part of their adult life in coaxing tiny cleaning wires through blocked holes in recorder pens, or other occupations of a similar order, might well break out in a craven sweat at the very idea of attempting analytical protein chemistry on extracts from single cells. Nevertheless, gel electrophoresis techniques have, for example, been developed to cope with quantities of protein in the nanogram range, or even below.

A variant that has now been described is isoelectric focusing, done in acrylamide gels of $1 \mathrm{~mm}$ or so diameter. Gainer (Anal. Biochem., 51, 646; 1973) has found it possible to fractionate proteins by this means, and to determine the isoelectric point of a $10^{-10} \mathrm{~g}$ sample. As in the usual gel electrofocusing technique, the polyampholyte, which is responsible for establishing the $p \mathrm{H}$ gradient, is included in the polymerization mixture. The separation, fixing and staining follow more or less the standard large-scale procedures, with certain variations, the trickiest manipulations being those concerned with application of the sample. Results with standard proteins show that the micromethod yields little in the precision of the measured isoelectric points to the standard procedure, using a thousand times more protein. Gainer has already applied the technique to the examination of proteins extracted from single neurones.

The sensitivity of fluorescence, especially of extraneous chromophores chosen for their high quantum yield and capable of attachment to proteins and amino acids, has likewise been put to good use for a number of microanalytical purposes, including, for example, endgroup determination. An interesting discovery is now reported by Kinoshita, Iinuma and Tsuji (Biochem. Biophys. Res. Commun., 51, 666; 1973), who found that the cyclic oligosaccharide, cycloheptaamylose, will sequester dansylamino acids in aqueous solutions, with a huge increase in the fluorescent intensity from the dansyl group. The enhancement is substantially insensitive to added solutes, other than those which them. selves form complexes with the saccha. ride. The sensitivity of the fluorescent assay is such that concentrations of the amino acids after dansylation can be determined at levels well below nanomolar. Kinoshita et al. have examined the interaction of the dansyl derivatives of all the common amino acids with cycloheptaamylose, and found that all form $1: 1$ complexes with rather similar free energies, but that the enthalpic and entropic contributions vary somewhat. The small, or unfavourable, entropy changes found for the hydrophobic amino acids can in principle be explained by solvation effects.

Another fluorometric assay for proteins, peptides and amino acids has been evolved by Udenfriend and his colleagues, who discovered that the ninhydrin reaction of primary amines could be modified by the inclusion of phenylacetaldehyde in the reagent, so as to generate a new and blindingly fluorescent chromophore. Since then the nature of this species has been established, and a

\title{
Global Tectonics in the Precambrian
}

DURING the past few years geologists have succeeded in establishing some of the types of geological structure formed early in the history of the Earth. It is, however, far from certain how these structures are related to one another and still less certain what systems of global tectonics operated early in the Precambrian. The successions of volcanic rocks preserved in the Precambrian greenstone belts have no exact analogue today; in some respects they resemble the volcanic materials which accumulate on island arcs but in other respects the rocks can be compared with the predominantly basaltic successions erupted along modern ocean ridges.

Particular attention has been paid to Precambrian anorthosites and it is now clear that in addition to the well known late Precambrian examples, anorthosites were formed rather extensively much earlier in the Precambrian. Two belts in particular have been identified; one extended from North America through Greenland into north-west Europe ; the other ranged from Central Africa through Madagascar into India.

Although the exact ages of the anorthosites in these belts are still imprecisely known, they seem to date from a period between 3,500 and 2,500 million years ago. It is known that granitic rocks had already evolved by that period, and this has led to the suggestion that the granitic rocks may represent early continental crust and the anorthositic associations might represent a type of Precambrian oceanic crust. Garson and Livingstone (see Nature Physical Science next Monday, June 4) apply this hypothesis to a small area rich in anorthosites which is exposed in South Harris off north-west Scotland; they suggest that the Scottish anorthosites and the associated rocks might represent a piece of oceanic crust thrust into juxtaposition with fragments of a Precambrian continent.

The areas available for study in the Outer Hebrides are so small that it is likely to prove very difficult to arrive at a reasonable interpretation of the large scale structural relations, but it may be possible to do this in Greenland or in the Canadian Shield where more extensive outcrops are present. In this connexion it is interesting to recall that $\mathrm{McGregor}$ reported recently that he and colleagues from the Greenland Geological Survey with experience in Western Greenland had arrived at a hypothesis which interpreted the anorthosite rich Precambrian regions in Greenland as primitive oceanic crust.

It will be of interest to see if further work confirms the suggestion arrived at independently by these two groups of workers, and whether future research can establish the relationships of the anorthosites to the greenstone belts and show whether or not these Precambrian igneous associations resemble in any way successions of igneous rocks erupted at the present day. 